\title{
HOW TO INCREASE ATTENTION TO ADVERTISEMENTS ACROSS BABY BOOMERS, X AND Y GENERATIONS
}

DOI: 10.17261/Pressacademia.2015211606

\author{
Ahmet Nihat Tavsan ${ }^{1}$ \\ ${ }^{1} Y e d i t e p e$ University. anihatt@hotmail.com
}

\section{Keywords \\ Advertising, attention, \\ $\mathrm{Y}$ generation, \\ $\mathrm{X}$ generation, Baby-Boomer.}

\begin{abstract}
The article includes examination of the general aspects of Baby Boomer, $\mathrm{X}$ and $\mathrm{Y}$ generations in terms of demographic and psychographic dimensions and focuses on adding a new cluster of dimensions to discriminate them regarding their attention level to the communication content and advertisements that they incur. In this study it is found out that the cohorts can be discriminated through their attention level on the shared platform of advertising appeals of ; Creativity, Celebrity Endorsement, Reference Group, Emotion Evoking and Sexual Connotation. The variance between the old and the young generations explained on the ground of existential philosophy.
\end{abstract}

\section{INTRODUCTION}

Advertisement should be wisely composed to ensure its effectiveness (Kirmani and Wright, 1989). Grabbing attention plays a significant role to secure the effectiveness of an advertisement (Moorman et al., 2012), since without grabbing attention an advertisement can't achieve the assigned goal (Pieters et. al. 2010).

Content is one of the major tools for an advertisement to be noticed (Krugman and Herbert, 1988), therefore marketers ought to compose right content in advertisements to grab attention, but it is hard to talk about single right on this issue. Right content to grab attention varies throughout segments; it varies through genders (Goodrich, 2014) (Nettelhorst et. al., 2012) , locations (Ateljevič et. al., 2011) (Dao et. al., 2012), cultures (Deleersnyder et. al., 2009) (Okazaki, 2015) (Czarnecka et. al., 2013) (Okazaki et. al., 2010) and so forth.

In this research it is studied whether generations as $X, Y$ and Baby Boomers can be discriminated in terms of their attention to advertisements through dimensions of Creativity (Lehnert and Ospina, 2014) (West et. al., 2013) (Reinartz and Saffert, 2013), Sexual Connotation (Schubert, 2012) (Torlak, 2011) (Furnham and Mainaud, 2011) (Malson, 2011), Celebrity Endorsement (Zwilling and Fruchter, 2013) (Kelting and Rice, 2013), Emotion Evoking (Faseur and Geuens, 2012) (Lowry and Correll, 2011) and Reference Group Exposure (Lessig, and Park, 1978) (Meirick, 2004) in attention context. 


\section{LITERATURE SURVEY}

\section{1. The Generations}

In parallel of having common demographic variables such as gender, geographical location, ethnicity, occupation and so forth, individuals are tend to have common attitudes and behaviors (Hildebrandt, 2011). The birth year variable is a popular segmentation tool used among researchers to understand the attitudes and behaviors of people masses (Petroulas et. al., 2010). In the frame of birth year factor, many researches contributed to the body of knowledge. Maybe the most common context in forming groups on birth year basis is the generations. In this study we employed this concept to understand the factors leveraging attention to advertisement through the perspective of $\mathrm{X}, \mathrm{Y}$ and Baby Boomer generations.

\subsubsection{Baby Boomers (1946 -1964)}

The individuals who were born between the years of 1946 to 1964 defined as baby boomers (Migliaccio, 2013), whereas the years are subject to incur little changes according to countries and cultures (Table 1).

Table 1: Birth Years of Baby Boomer Cohort Across Countries

\begin{tabular}{|l|c|c|}
\hline Country & Beginning Year & Ending Year \\
\hline USA & 1946 & 1964 \\
\hline France & 1946 & 1974 \\
\hline United Kingdom & 1946 & 1971 \\
\hline Portugal & 1945 & 1960 \\
\hline Australia & 1945 & 1965 \\
\hline Turkey & 1946 & 1964 \\
\hline Canada & 1947 & 1966 \\
\hline
\end{tabular}

Source: (Hernaus, and Vokic 2014), (Yaşa and Mucan, 2010), (Tavener and Byles, 2014), (Trevor, 2007), (Tang et. al., 2012), (Adiguzel et. al., 2014), (Santos et. al., 2012), (Lyons et. al., 2014)

The generation gets the name from sharp decrease and increase in birth rate due to natural reflection of World War II (Tavener and Byles, 2014). The cohort is known for its financial prosperity (Yaşa and Mucan, 2010), (Heaney, 2007), that renders them meaningful targets for savvy marketers. The generation has had lower rates of marriage regarding the previous generations (Trevor, 2007). They are hardworking, idealist and harmonious individuals (Adiguzel et. al., 2014). Tang et. al. credits the generation as job loyal comparing $X$ and $Y$ Generations since they give higher value to work itself than other generations give (Tang et. al., 2012). According to Heaney, Baby Boomers are committed to brands (Heaney, 2007). 


\subsubsection{Generation (1965-1979)}

Even in some sources they are defined with different periods(Table 2), in general assumption X cohort starts by the year of 1965 and lasts till 1979 (Alwin, 2002).

Table 2: Birth Years of $X$ Cohort Across Countries

\begin{tabular}{|l|c|c|}
\hline Country & Beginning Year & Ending Year \\
\hline USA & 1965 & 1980 \\
\hline France & 1961 & 1980 \\
\hline United Kingdom & 1964 & 1980 \\
\hline Australia & 1965 & 1976 \\
\hline Turkey & 1965 & 1979 \\
\hline Canada & 1964 & 1979 \\
\hline Portugal & 1961 & 1980 \\
\hline
\end{tabular}

Source: (Reisenwitz and Iyer, 2009), (Gurau, 2012), (Hernaus, and Vokic 2014), (Keene and Handrich, 2011), (Alwin, 2002), (Tavener and Byles, 2014), (Yaşa and Mucan, 2010), (Santos et. al., 2012), (Heaney, 2007), (Lyons et. al., 2014), (Yolbulan and Yalman, 2013)

The generation is also called as "baby busters" (Valkeneers and Vanhoomissen, 2012), "lost generation" (Pritchard and Whiting 2014) or "sandwich generation" as they feel the pressure of both predecessor and successor generations (Keene and Handrich, 2011). They earn less regarding Baby Boomers so comparing them they represent a financially despondent cohort (Yaşa and Mucan, 2010). They are qualified professionals and seek advancement as well as are demanding quality time (Keene and Handrich, 2011). According to Reisenwitz and lyer, they avoid risks (Reisenwitz and lyer, 2009) and it guides us to understand their brand loyal attitude (Reisenwitz and lyer, 2009) comparing Generation Y, although they are very skeptical consumers (Heaney, 2007).

\subsubsection{Y Generation (1980-2001)}

There are different approaches regarding the exact period of generation $\mathrm{Y}$ (Table 3). In the presence of slight changes the period covers the years between 1980 and 2001(Adiguzel et. al., 2014) and in this study the assumption employed.

Table 3: Birth Years of Y Cohort Across Countries

\begin{tabular}{|l|c|c|}
\hline Country & Beginning Year & Ending Year \\
\hline USA & 1981 & 1993 \\
\hline France & 1981 & 1995 \\
\hline United Kingdom & 1980 & 1995 \\
\hline Portugal & 1981 & - \\
\hline Australia & 1977 & - \\
\hline Turkey & 1980 & 2001 \\
\hline Canada & 1980 & - \\
\hline
\end{tabular}

Source: (Tavener and Byles, 2014), (Trevor, 2007), (Hernaus, and Vokic 2014), (Yaşa and Mucan, 2010), (Hernaus, and Vokic 2014), (Gurau, 2012), (Keene and Handrich, 2011), (Adiguzel et. al., 2014), (Santos et. al., 2012), (Heaney, 2007), (Lyons et. al., 2014), (Reisenwitz and lyer, 2009), (Kuşçu and Özçam, 2014). 
The generation also called with other names as; Echo Boomers, Boomlets, Millennium Generation (Heaney, 2007), Millennials (Lyons et. al., 2014) and so forth. They are; highly involved with technology, environment-sensitive (Gurau, 2012), positive individuals, who credit to product with cool images and are open to diversity that globalization brings (Heaney, 2007). They are not loyal to their job as previous generations do, rather they prefer a boundryless path (Lyons et. al., 2014). They have high level of multi task processing capability but are easily bored (Lower, 2008). In terms of brand loyalty and ambiguity avoidance they are the last in trio (Reisenwitz and Iyer, 2009).

\subsection{The Discriminating Dimensions}

As we discussed, generations differ from each other not only by demographic variables but also via psychographics variables. Through a retrospective view, we witness a freedom act in line with the communication diversity across cohorts. As the generations go younger, they tend to be more informal, participative and result oriented (Table 4).

Table 4: General Characteristics of Cohorts

\begin{tabular}{|c|c|c|c|c|}
\hline & \multirow{2}{*}{ ATTRIBUTE } & \multicolumn{3}{|c|}{ COHORT } \\
\hline & & Baby Boomers & Generation X & Generation Y \\
\hline 1 & $\begin{array}{l}\text { General } \\
\text { Structure }\end{array}$ & $\begin{array}{l}\text { Optimistic, } \\
\text { idealistic, goal- } \\
\text { driven, critical, } \\
\text { tolerant, self- } \\
\text { centered, } \\
\text { self-sufficient, } \\
\text { materialistic }\end{array}$ & $\begin{array}{l}\text { Individualistic, } \\
\text { pragmatic, } \\
\text { cautious, } \\
\text { cynical/skeptical, } \\
\text { informal, } \\
\text { independent, } \\
\text { self-reliant, flexible }\end{array}$ & $\begin{array}{l}\text { Optimistic, } \\
\text { ambitious, confident, } \\
\text { high self-esteem, } \\
\text { moral, socially } \\
\text { responsible, have } \\
\text { diversity } \\
\text { consciousness }\end{array}$ \\
\hline 2 & Style & $\begin{array}{l}\text { Process and result } \\
\text { oriented, value } \\
\text { personal } \\
\text { interactions when } \\
\text { communicating, } \\
\text { overly sensitive to } \\
\text { feedback, distrust } \\
\text { authority, }\end{array}$ & $\begin{array}{l}\text { Comfortable with } \\
\text { competition, } \\
\text { entrepreneurial, } \\
\text { outcome-oriented, } \\
\text { value quality over } \\
\text { quantity, seek } \\
\text { work-life balance, } \\
\text { poor team players }\end{array}$ & $\begin{array}{l}\text { Technologically } \\
\text { savvy, multitasking } \\
\text { capabilities, look for } \\
\text { meaning, strong } \\
\text { sense of fairness and } \\
\text { ethics, } \\
\text { achievement/results- } \\
\text { oriented, respect } \\
\text { diversity }\end{array}$ \\
\hline 3 & $\begin{array}{l}\text { Social } \\
\text { Approach }\end{array}$ & Team player & Entrepreneur & Team oriented \\
\hline 4 & $\begin{array}{l}\text { Communicat } \\
\text { ion Base }\end{array}$ & Face-to-face & E-mail & Real time messaging \\
\hline
\end{tabular}

Source: Compiled through (Hernaus, and Vokic 2014), (Keene and Handrich, 2011)

Mentioned demographic and psychographic dimensions are discriminating the generations. With the conducted study, we tested to add a new cluster of dimensions on the ground of attention to advertisements, to underline the difference between generations. 
We tested the hypothesis whether cohorts can be discriminated on the shared platform of five major contexts; Creativity, Sexual Connotation, Celebrity Endorsement, Emotion Evoking and Reference Group Exposure, which prospectively affect the level of attention in regard to their characteristics.

\subsubsection{Creativity}

Creativity is one of the important components of advertising and a key consideration for firms that desire more return on investment (Lehnert et. Al., 2014). Due to its role, it keeps attracting the researches to study over it. According to Ahlin et. al. the creativity concept is mostly commemorated with newness and difference (Ahlin et. al., 2013). On the other hand newness means not being obsolete, in other words it corresponds to the intention to challenge to and even change the existing paradigm. The word of obsolete is synonym of being old fashioned, therefore newness tends to represent the other polar: means youth. Peng et. al. in their researches revealed that as the experience of an individual increases, the creativity of the individual decreases (Peng et. al., 2013). The priceless source of experiencing is the time, correspondingly as the time lived accumulates, experience accumulates and creativity shortens. Ergo, the old should be more insensitive to the institution of creativity, consequently it is rational to think that creativity and attention to creativity should be correlated with young age. Studies of (Agogué et. al., 2013), (Chan et. al., 2013) supports the argument as in their researches they found correlations with youth and creativity contexts. From the point we can start building hypothesis and say that creativity should have contribution to discriminate generations due to their young-old polarized state. Based on the conclusion we form our H1: Creativity concept has significant effect to discriminate generations in terms of their attention level to advertisements.

\subsubsection{Celebrity Endorsement}

Celebrity endorsement is a credited strategy to gain attention and raise return on investment (Hung, 2014). The fact behind the concept is letting audience to pair the positive feelings of the celebrity with the offered product or service (Bush et. al., 2004) as a conditioning process. The principle aims to transfer positive associations from source (celebrity) to target (product/service). According to Austin et. al., celebrities are likely to influence people at young age (Austin et. al., 2008), whereas Maronick in his research postulated that the old are less likely to be influenced by a celebrity in the presence of a rationale (Maronick, 2005). In the light of previous studies we can add celebrity endorsement to our model by claiming that it has contribution to discriminate generations in terms of their determinant that raise attention to advertisements. Based on the syllogism we form H2: Celebrity endorsement concept has significant effect to discriminate generations in terms of their attention level to advertisements.

\subsubsection{Sexual Connotation}

Even using sexuality in advertising is regarded as unethical and a sort of dehumanization (Bongiorno et. al., 2013), sexual connotation is a widely used tool in marketing programs and sex sells motto is still embraced by various industries (King et. al., 2015). At the same time, according to Chang and Tseng (Chang and Tseng, 2013) the effectiveness of the advertisement with sexual content is higher than without sexual content. 
This is an ethics versus logic dilemma that marketers have to cope with. On the contrary, studies that postulated by Ma, Chernyshkova and Kalra et. al., revealed that sexuality and its associations such as love, desire and intimacy are more like to be experienced in youth (Ma, 2014), (Chernyshkova, 2010), (Kalra et. al., 2011). Additionally as the age goes up, libido of people is more likely to reduce (Jeong et. al., 2012), therefore people with older age more likely to engage with sexuality related activities less frequently regarding the young, in other terms the old are in a state of low involvement. According to cognitive theory, low involvement produces less attention (Celsi and Olson, 1988). Due to these facts the younger are tend to pay more attention to sexual connotation regarding the old. So we can add the variable to our hypothesis' platform as sexual connotation in advertising has contribution to discriminate cohorts. Based on the evidences we form our H3: Sexual connotations have significant effect to discriminate generations in terms of their attention level to advertisements.

\subsubsection{Emotion Evoking}

In advertising strategies, the emotion evoking tool is used in an increasing manner (Roozen, 2013). Conforming to Hofer et. al., as the age increase, people have more control over their behaviors in the presence of emotion evoking stimuli (Hofer et. al. 2015). In other terms the old are able to produce more tolerance to emotions regarding the young. Additionally, according to research of Loureiro and Roschk, the descending direction of age difference, positively affects the loyalty level of audience across cohorts in depending on the emotional responses and its behavioral reflections (Loureiro and Roschk, 2014). Besides, the research of Isaacowitz et. al. puts front that the old are physically might be at lower state regarding to young to perceive the emotional stimuli (Isaacowitz et. al., 2015). Therefore the young are inclined to attend emotion evoking stimuli comparing the old. Thus we can add this dimension to the model as a discriminating independent. Based on the conclusion we form our H4: Emotion evoking concept has significant effect to discriminate generations in terms of their attention level to advertisements.

\subsubsection{Reference Group Exposure}

According to existentialist philosophy, human finds himself under the load of "the freedom to choose" with the existence (Gravil, 2007). The freedom to choose is a load since it assigns responsibility to human and the individual shall choose the option and bear the psychological, sociological and economical outcomes of that choice and the probability to choose the wrong option stresses the individual (Gravil, 2007). People in order to be freed from the stress of freedom might choose not to make their own choices but rather to follow someone else whom they took as reference (Irmak et. al., 2010). By the way individual would transfer the responsibility. From the perspective of existential philosophy reference group concept can be explained in this context. Furthermore, as the age goes up, people accumulate experiences and they become less likely to take the reference group in to account comparing the young (Şimşek and Demir, 2014). Thus we form our H5: that "Reference Group Exposure" as an independent variable has prospect main effect in discriminating cohorts. Till now we formed five hypothesis and all are proposed to discriminate generation, so based on the hypothesis' we form our sixth and the last hypothesis as H6: Baby Boomer, $X$ and $Y$ Generations can be discriminated in terms of their attention level to advertisement on the shared platform of the stated 
quintet (Creativity, Celebrity Endorsement, Sexual Connotation, Emotion Evoking and Reference Group Exposure),(Figure 1).

Figure 1: Hypothesized Multinomial Logistic Regression Model

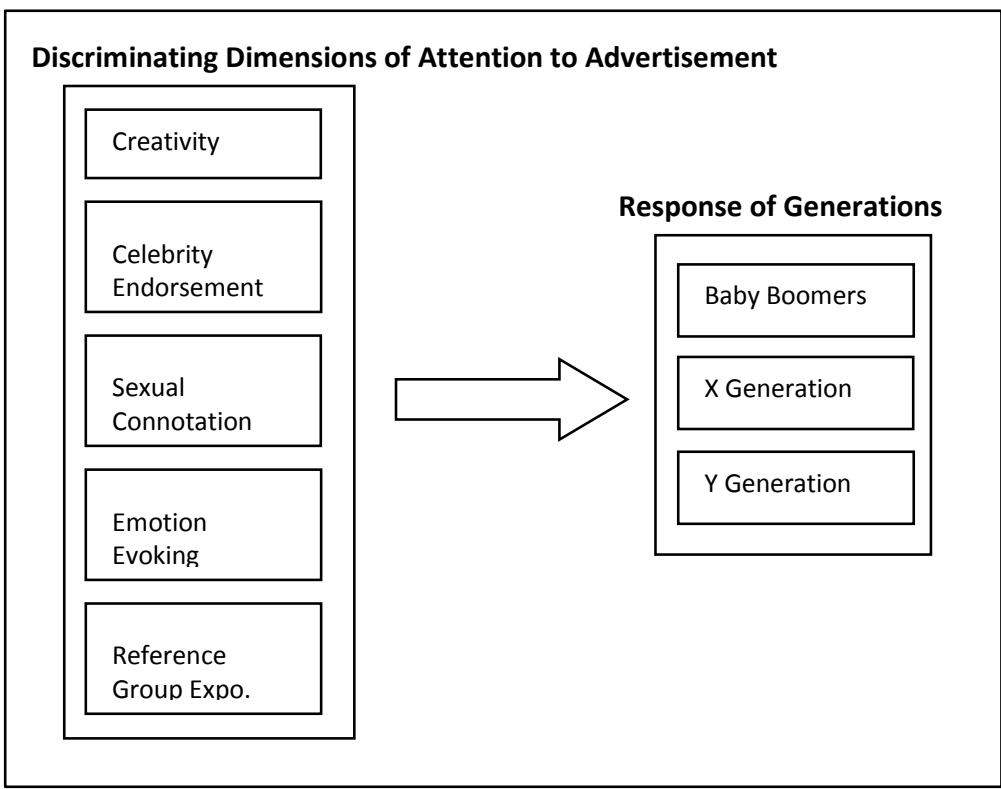

\section{DATA AND METHODOLOGY}

\subsection{Participants}

Four hundred sixty-six respondents participated to research (249 female, 214 male and 3 respondents did not provide gender information). Participants' ages were ranging from 14 to 69.122 of them belong to Baby Boomers, 161 of them belong to $X$ generation and 183 of them belong to $Y$ generation (Table 5). The mean age for members of the cohorts of $Y$, $X$ and Baby Boomer were 24,46 (SD 5,676), 42,65 (SD 4,109) and 58,41 (SD 4,464) respectively. Simple random sampling was used in sampling procedure.

Table 5: Gender vs Cohort Crosstabulation

\begin{tabular}{|l|c|c|c|c|}
\cline { 2 - 5 } \multicolumn{1}{c|}{} & Generation X & Generation $\mathbf{Y}$ & Baby Boomers & Total \\
\hline Male & 81 & 81 & 52 & 214 \\
\hline Female & 102 & 78 & 69 & 249 \\
\hline Not Provided & 0 & 2 & 1 & 3 \\
\hline Total & 183 & 161 & 122 & 466 \\
\hline
\end{tabular}




\subsection{Tools}

A five itemed instrument developed to measure "Discriminating Dimensions of Attention to Advertisements". Measurements done through 7 pointed, balanced, unipolar itemized rating scales. After giving brief information regarding the study, it is asked respondents to fill the questionnaire. Only people, who are eligible to read and write, participated to study.

\subsection{Methodology}

Multinomial logistic regression method was conducted to test the hypothesis $H 1, H 2, H 3$, H4, H5. Later Principal Component Analysis was run to test whether stated dimensions of Creativity, Celebrity Endorsement, Reference Group, Emotion Evoking and Sexual Connotation are measuring the same core concept. Later the variables tested through Confirmactory Factor Analysis. Following to internal consistency analysis the variables summated and created a new variable. Later the variable treated multinomial logistic regression analysis.

\section{EMPIRICAL FINDINGS}

Logistic regression method was conducted to test the hypothesis $\mathbf{H} \mathbf{1}, \mathbf{H} \mathbf{2}, \mathbf{H} \mathbf{3}, \mathbf{H} \mathbf{4}, \mathbf{H} \mathbf{5}$ and H6. According to findings:

H1 was accepted with a significance figure of 0,000 . The model had a explanatory power of 0,307 (Nagelkerke) which was below the high explanatory power of level of 0,500. Taking the baby boomers as reference, generation $X$ and $Y$ has scores of 2,082 and 3,634 respectively. The variable could classify the cohort in \%59,9 accuracy. The results put front that as the age goes down, creativity becomes a affective point to attend an ad.

H2 was accepted with a significance figure of 0,000 . The model had an explanatory power of 0,308 (Nagelkerke) which was below the high explanatory power level of 0,500. Taking the baby boomers as reference, generation $X$ and $Y$ has scores of 2,382 and 3,869 respectively. The variable could classify the cohort in \%58,6 accuracy. The results put front that as the age goes down, people are tend to attend an ad in the presence of a celebrity.

H3 was accepted with a significance figure of 0,000 . The model had an explanatory power of 0,280 (Nagelkerke) which was below the high explanatory power of level of 0,500. Taking the baby boomers as reference, generation $X$ and $Y$ has scores of 2,166 and 3,813 respectively. The variable could classify the cohort in $\% 61,8$ accuracy. The results put front that sexual connotation has discriminating affect over cohorts. As the age goes down, likelihood to engage with an ad with sexual connotation sharpens.

H4 was accepted with a significance figure of 0,000. The model had an explanatory power of 0,318 (Nagelkerke) which was below the high explanatory power of level of 0,500. Taking the baby boomers as reference, generation $X$ and $Y$ has scores of 2,196 and 4,047 respectively. The variable could classify the cohort in \%61,2 accuracy. The results imply that emotion evoking has discriminating affect over cohorts and emotion evoking stimuli less likely to call attention of old regarding young generations.. 
H5 was accepted with a significance figure of 0,000. The model had an explanatory power of 0,346 (Nagelkerke) which was below the high explanatory power of 0,500.

Taking the baby boomers as reference, generation $X$ and $Y$ has scores of 2,404 and 4,184 respectively. The variable could classify the cohort in \%61,4 accuracy. The finding support that reference group exposure has affect to discriminate cohorts in terms of their attention level to ads. The in negatively correlated with attention level to ads on the platform of reference group exposure.

Till now, all our hypothesis validated, on the other hand, none had a high explanatory power. In order to increase the explanatory power of the power of model, we summated. Before summating them, a few test conducted to measure whether they scientifically measure the same concept. At first stage Principal Component Analysis was conducted. Varimax rotation method was applied. The analysis produced one component, all five dimensions took place in this component. KMO had a figure of 0,914 and Bartlett's test of sphericity produced significant result, so the dimension reduction attempt came end with a validation. The finding supported that the dimensions was measuring the same concept.

Later we treated confirmatory factor analysis to data in order to test the construct validity of the independents. The result of the goodness of fit test was insignificant $(0,158)$, it showed that predetermined model fitted to our sample data. Besides, KMO had a figure of 0.914 , which indicated that the sample size was enough to conduct factor analysis as it was over cutoff value of 0,50 (Ebrahimy and Osareh, 2014). Furthermore, Bartlett's test of sphericity was significant which supported the reliability of the confirmatory factor analysis (Ebrahimy and Osareh, 2014). Oblimin rotation was carried out as the average loading of the component calculated as 0,7338 , since the result was more than 0,70 , the convergent validity succeeded (Békaert et. al., 2012). It also signified that the model had an oblique structure, means the correlation between factors were away of being orthogonal.

After securing the convergent validity of the model, internal consistency of five dimensions examined. Cronbach's Alpha was 0.947, which was far above the cutoff value of 0,70 (Cronbach, 1951), means the result supported the confirmatory factor analysis as the factors were measuring the same concept. Hence the items consolidated through summation method and obtained one independent variable.

After summating independent variables Multinomial Logistic Regression conducted to test the hypothesis. Instead of Wald, Likelihood-ratio method used to test the model fitting in order to avoid any probable quandary that Wald method may bear (Walter et. al., 1977). Both likelihood ratio final model fitting test and Pearson goodness of fit test had a value of 0,000 , which showed that the dispersion that model proposed is validated in terms of fitness (Mebane and Sekhon, 2004). According to the output, H6 is accepted as model fitted the data. Nagelkerke pseudo $R^{2}$ had a figure of 0,506 . It indicated that the model had a high explanatory power to discriminate generations in terms of their motivation on advertisements. Model could classify the members of cohorts with a high accuracy of $\% 74,2$ (Table 6), which was far above the cutoff point of 0,50 (Peng et. al., 2002), the finding supported that model wasn't explaining the variance by chance. 
Table 6: Cohort Classification Table

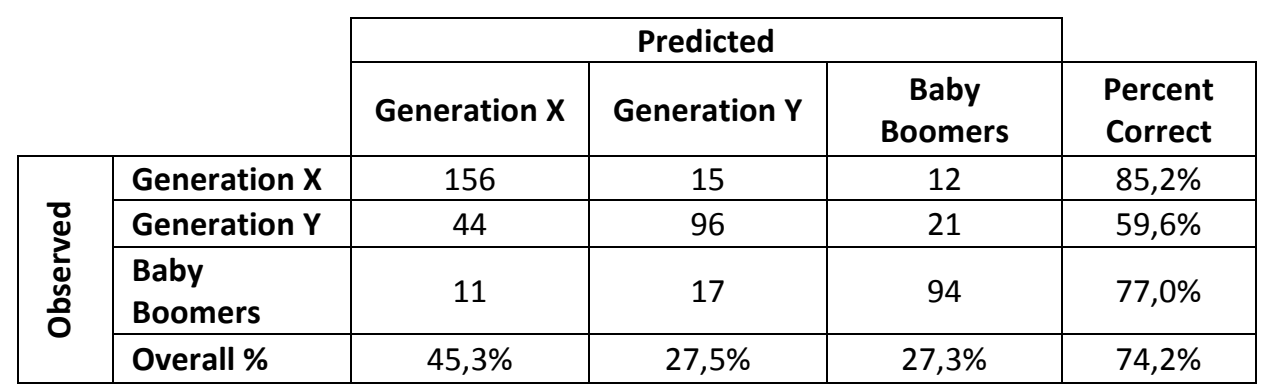

In parameter estimates table all cohorts had significant results, which implied that three out of three cohorts had significant contribution to the explanatory power of the regression model (Table 7 ).

Table 7: Contribution of Cohorts to Model

\begin{tabular}{|l|l|c|c|c|c|}
\cline { 3 - 6 } \multicolumn{2}{c|}{} & B & Std. Error & Wald & Significance \\
\hline \multirow{2}{*}{ Generation Y } & Intercept & 6,831 & 1,291 & 27,984 & 0,000 \\
\cline { 2 - 6 } & Score & $-0,355$ & 0,067 & 28,312 & 0,000 \\
\hline \multirow{2}{*}{ Generation X } & Intercept & 4,036 & 1,140 & 12,526 & 0,000 \\
\cline { 2 - 6 } & Score & $-0,170$ & 0,048 & 12,417 & 0,000 \\
\hline
\end{tabular}

Note: The reference category is: Baby Boomers

\section{CONCLUSION}

The results imply that as the generations go younger, they tend to be more sensitive to Creativity, Sexual Connotation, Celebrity Endorsement, Emotion Evoking and Reference Group Exposure regarding old generations. Consequently, when developing marketing programs, organizations can benefit from the finding to make more accurate decisions in their commercial compositions regarding their target audience.

Our findings also supports the previous studies, as people get old, they gradually turn their faces from mundane concepts (Osajima et. al., 2010), (Clark, 2000). On the contrary very few members of the Baby Boomer cohort received high scores and fell to the region of either Generation X or Generation Y boarders (Table 6). The situation can be explained with the fear of death. According to Burroughs et. al. when people are afraid of death, they develop the feeling of existential insecurity. Due to the insecurity, those people tend to embrace physical world and expose materialist behaviors (Burroughs et. al., 2013). Moreover from empirical and academic knowledge we know that the old are more likely to die regarding the young and it makes them to think over nonexistence more regarding the young. Therefore, the Baby Boomers who received high scores in this instrument can be evaluated as more materialistic as well as are afraid of death more regarding the other Baby Boomers. According to results (Table 6), eleven out of hundred and twenty-two boomers, -which corresponds to a ratio of \%9-, experience existential insecurity. While clustering the participants into cohorts, the birthdays weren't taken into consideration, all participants evaluated as to be born in 1st of January. The study conducted in major cities so it may or may not reflect the intentions of the individuals in rural areas. 
Through the research we found out which dimensions catch the attention of the young, as well as what dimensions does not grab the attention of the old. A further research might be conducted to find out what dimension leverage attention of the old regarding the young individuals.

\section{REFERENCES}

Adiguzel, O, Batur. H, Z., Eksili, N., (2014) “Generation's Changing Side and The Newly Arisen Work Style After YGeneration: Mobile Collars", Journal of Süleyman Demirel University Institute of Social Sciences Issue: 2014/1, Number:19 p.166 - 182

Agoguéa, M., Poirel, N., Pineaub, A., Houdéb O., Cassotti, M.(2013) "The impact of age and training on creativity: A design-theoryapproach to study fixation effects" Thinking Skills and Creativity, (11) p.33-41

Ahlin, B., Drnovsek, M., Hisrich, R. D., (2013) “Entrepreneurs' creativity and firm innovation: the moderating role of entrepreneurial self-efficacy" Small Business Economics, 43, p.101- 117

Alwin, D. F. (2002) "Generations X, Y And Z: Are They Changing America”, American Sociological Association, Contexts, 42 /1, p.42- 51

Ateljevič, Jovo; Martin, Frank. (2011). "The Use of Location Specific Advertisements on Facebook: Can They Help Entrepreneurs Solve Problems Associated With Banner Advertisements?", Challenges of Europe: Growth \& Competitiveness - Reversing Trends: Ninth International Conference Proceedings, p17-32. 16p.

Austin, E. W., Van de Vord, R., Pinkleton, B. E., Epstein E. (2008) “Celebrity Endorsements and Their Potential to Motivate Young Voters" Mass Communication and Society, 11:4, p.420-436

Békaert, J., Masclet, G. Caron, R. (2012) "Psychometric validation of the inventory of the resilience factors" Psychologie Francaise, March, 57(1), pp.51-61

Bongiorno,R., Bain, P. G., Haslam, N. (2013) “When Sex Doesn't Sell: Using Sexualized Images of Women Reduces Support for Ethical Campaigns", Plos One, December, Vol. 8, Issue 12, e83311, p. 1 - 6

Burroughs, J. E., Chaplin, L. N., Pandelaere, M., Norton, M. I., Ordabayeva, N., Gunz, A., Dinauer, L. (2013). “Using Motivation Theory to Develop a Transformative Consumer Research Agenda for Reducing Materialism in Society" Journal Of Public Policy \& Marketing, 32(1), p. 18-31.

Bush, A. J., Martin, C. A., Bush, V.D. (2004) "Sports Celebrity Influence on the Behavioral Intentions of Generation Y" Journal of Advertising, March, p.108-118

Celsi, R. L., Olson, J. C. (1988) "The Role of Involvement in Attention and Comprehension Processes" Journal of Consumer Research, Vol. 15, September, p.210-224

Chan, K., Hui, A., Cheng, S., Ng, Y. L. (2013) "Perceptions of Age and Creativity in the workforce", The Journal of Creative Behavior, Vol. 47, Iss. 4, pp. 256-272

Chernyshkova, E. V. (2011) "Sexual Activity in Old Age" Saratov Journal of Medical Scientific Research. Vol. 7, № 3. p.693-694

Clark, T. N. (2000) “Is Materialism Rising in America” Society, Sep-Oct, (6), p.47-48

Cronbach, Lee., (1951) "Coefficient Alpha and the Internal Structure of Tests", Psychometrika; Sep, Vol. 16 Issue 3, pp.297-334

Czarnecka, B.; Stephan D., Stephan; Eagle, L., (2013). “Is food advertising culture-bound? Contradictory Results from Three European Countries". Journal of Customer Behaviour. Summer/Autumn, Vol. 12 Issue 2/3, p227-246.

Dao, T. H., Jeong, S. R., Ahn, H., (2012). “A novel recommendation model of location-based advertising: ContextAware Collaborative Filtering using GA approach", Expert Systems With Applications. 2012 39(3):3731-3739

Deleersnyder, B., Dekimpe, M. G., Steenkamp, Jan-Benedict E.M; Leeflang, Peter S.H. (2009) “The Role of National Culture in Advertising's Sensitivity to Business Cycles: An Investigation Across Continents", Journal of Marketing Research, October, Vol. 46 Issue 5, p623-636.

Ebrahimy, S., Osareh. F. (2014) “Design, validation, and reliability determination a citing conformity instrument at three levels: normative, informational, and identification" Scientometrics, May, Vol. 99 Issue 2, p581-597 
Faseur, T.; Geuens, M. (2012) "On the Effectiveness of Ego- and Other-Focused Ad-Evoked Emotions". International Journal of Advertising. Vol. 31 Issue 3, p529-546

Furnham, A.; Mainaud, L. (2011) "The Effect of French Television Sexual Program Content on the Recall of Sexual and Nonsexual Advertisements"., Journal of Sex Research,. Nov/Dec, Vol. 48 Issue 6, p590-598

Goodrich, K., (2014) "The Gender Gap: Brain-Processing Differences Between the Sexes Shape Attitudes About Online Advertising", Journal of Advertising Research. March, Vol. 54 Issue 1, p32-43

Gravil, R. (2007) “Existentialism” Humanities-Ebooks: p.32

Gurau, C., (2012) "A life-stage analysis of consumer loyalty profile: comparing Generation X and Millennial consumers", Journal of Consumer Marketing, Vol. 29 Iss 2 pp. $103-113$

Güdekli, İ. A., Çelik, İ. (2014) "Using Woman in Advertisement as a Symbol of Sex: Cosmopolitan Magazine Example". Journal Of Yasar University, 35(9), p.6129-6137

Heaney, J. (2007) "Generations $X$ and $Y$ 's internet banking usage in Australia" Journal of Financial Services Marketing Vol. 11, 3, p.196-210

Hernaus, T., Vokic N.P. (2014) "Work design for different generational cohorts: Determining common and idiosyncratic job characteristics", Journal of Organizational Change Management, Vol. 27 Iss 4 pp. 615 - 641

Hildebrandt, S., (2011) "Marketing through the generations: identifying the wants and needs of age groups", Beverage Industry. Oct, Vol. 102 Issue 10, p16-20.

Hofer, M., Burkhard, L., Allemand, M. (2015) “Age Differences in Emotion Regulation During a Distressing Film Scene" Journal of Media Psychology, January p. 1-7

Howe, N., Strauss, W., (2007) “The Next 20 Years: How Customer and Workforce Attitudes Will Evolve”, Harvard Business Review, July-August, pp. $41-52$

Hung, K. (2014) "Why Celebrity Sells: A Dual Entertainment Path Model of Brand Endorsement" Journal of Advertising, 43(2), p. 155-166

Irmak, C., Vallen, B., Sen, S. (2010) "You Like What I Like, but I Don't Like What You Like: Uniqueness Motivations in Product Preferences" Journal of Consumer Research, Vol. 37, October, p.443-455

Isaacowitz, D. M., Livingstone, K. M., Harris, J. A., Marcotte S. L. (2015) “Mobile Eye Tracking Reveals Little Evidence for Age Differences in Attentional Selection for Mood Regulation" Emotion, Vol 15(2), Apr, 2015. p. 151161

Jeong, H. C., Kim, S. U., Lee, W. C., Kim, M. T., Lee, W. K., Kim, H.Y., Kim, S.Y., Yang, D. Y. (2012) “Sexual Behavior of the Elderly in Urban Areas", World J Mens Health, December 30(3) p.166-171

Kalra, G., Subramanyam1, A., Pinto, C. (2011) "Sexuality: Desire, activity and intimacy in the elderly" Indian Journal of Psychiatry, 53(4), Oct-Dec, p.300-306

Keene, D. L., Handrich, R. R., (2011) "Generation X members are "active, balanced and happy".Seriously?", American Society of Trial Consultants, Volume 23, Issue 6, November, p.29-43

Kelting, K.; Rice, D. H..(2013) "Should We Hire David Beckham to Endorse our Brand? Contextual Interference and Consumer Memory for Brands in a Celebrity's Endorsement Portfolio"., Psychology \& Marketing. July, Vol. 30 Issue 7, p602-613.

King, J., Mcclelland, A., Furnham, A. (2015) "Sex Really Does Sell: The Recall of Sexual and Non-sexual Television Advertisements in Sexual and Non-sexual Programmes", Applied Cognitive Psychology, 29, p. 210-216

Kirmani A., Wright P., (1989) "Money Talks: Perceived Advertising Expense and Expected Product Quality". Journal of Consumer Research, December, Vol.16, pp. 344-353

Krugman, Herbert E., (1988) "Point of View: Limits of Attention to Advertising”, Journal of Advertising Research. Oct/Nov, Vol. 28 Issue 5, p47-50. 4p.

Kruskal, W. H., Wallis, W. A. (1952) "Use of Ranks in One-Criterion Variance Analysis", Journal of the American Statistical Association, Vol. 47, Issue 260, p. 583-621;,

Kuşçu, A., Özçam D. S., (2014) “Analyzing Factors Affecting Repurchase Intention During Gezi Park Brand Protests", European Journal of Business and Management, Vol.6, No.38, pp.177 - 188 
Lehnert, K.; Till, B. D.; Ospina, J. M., (2014) “Advertising Creativity: The Role of Divergence Versus Meaningfulness", Journal of Advertising. Fall, Vol. 43 Issue 3, p274-285.

Lessig, V. P.; Park, C. W..(1978) "Promotional Perspectives of Reference Group Influence: Advertising Implications"., Journal of Advertising. Spring, Vol. 7 Issue 2, p41-47.

Loroz, P. S., Helgeson, J. G., (2013) “Boomers and Their Babies: An Exploratory Study Comparing Psycholological Profiles and Advertising Appeal Effectiveness Accross Two Generations" Journal of Marketing Theory and Practice, vol. 21, no. 3 (summer 2013), pp. 289-306

Loureiro, S. M. C., Roschk, H.(2014) “Differential effects of atmospheric cues on emotions and loyalty intention with respect to age under online/offline environment" Journal of Retailing and Consumer Services, 21, p.211-219

Lower, J.. (2008) “Brace Yourself here comes generation Y Critical Care Nurse" October 2008, 28/5 p.80-85

Lowry, J.; Correll, C.. (2011) "When it comes to advertising...Evoking emotions = more conversions"., Label \& Narrow Web. Nov/Dec, Vol. 16 Issue 8, p114-114

Lyons, S. T., Schweitzer, L., Eddy, S.W. (2014) “How have careers changed? An investigation of changing career patterns across four generations", Journal of Managerial Psychology, Vol. 30, Iss 1, pp. 8- 21

Ma, L. (2014) “Love Through the Ages”, Psychology Today, Sep/Oct, Vol. 47 Issue 5, p96

Malson, H.; Halliwell, E.; Tischner, I.; Rúdólfsdóttir, A., (2011) “Post-feminist Advertising Laid Bare: Young Women's Talk About the Sexually Agentic Woman of 'Midriff' Advertising”. Feminism \& Psychology. Feb, Vol. 21 Issue 1, p74-99.

Maronick, T. J. (2005) “Celebrity versus Company President as Endorsers of High Risk Products for Elderly Consumers" Journal of Promotion Management, Vol. 11(4), p.63-80

Mebane, W. R., Sekhon, S. J. (2004) "Robust Estimation and Outlier Detection for Overdispersed Multinomial Models of Count Data" American Journal of Political Science, Vol. 48, No. 2, Apr, pp. 392-411

Meirick, P. C., (2004) "Topic-relevant reference groups and dimensions of distance: political advertising and firstand third-person effects", Communication Research. April, Vol. 31 Issue 2, p234.

Migliaccio, J. N., (2013) "Urban Myths, Baby Boomers, and the Effective Financial Professional" Journal of Fianncial Service Proffesionals, May, p.33-40.

Moorman, Marjolein; Willemsen, Lotte M.; Neijens, Peter C.; Smit, Edith G., (2012) "Program-Involvement Effects on Commercial Attention and Recall of Successive and Embedded Advertising", Journal of Advertising. Summer, Vol. 41 Issue 2, p25-37.

Nettelhorst, Stephen C.; Brannon, Laura A.(2012) "The Effect of Advertisement Choice, Sex, and Need for Cognition on Attention", Computers in Human Behavior. July, Vol. 28 Issue 4, p1315-1320

Okazaki, S., Mueller, B., Taylor, C. R., (2010)“Global Consumer Culture Positioning: Testing Perceptions of SoftSell and Hard-Sell Advertising Appeals Between U.S. and Japanese Consumers", Journal of International Marketing., Vol. 18 Issue 2, p20-34. 15p

Okazaki, S.., (2015) “Do Global Brands Use Similar Executional Styles Across Cultures? A Comparison of U.S. and Japanese Television Advertising" Journal of Advertising, In Press, 14 January, 13p

Osajima, K., Sternquist, B., Manjeshwar, S. (2010) “Japanese Materialism: A Comparison Between the New Breed and Second Baby-boomer Age-cohorts", Journal of Asia Business Studies, Vol. 4 Iss: 2, pp.57 - 72

Peng C-Y.J., Lee K.L., Ingersoll G.M., (2002) “An introduction to logistic regression analysis and reporting” Journal of Educational Research, 96(1), pp.3-14.

Peng, J., Zhang, G., Fu, Z., Tan, Y. (2014) “An empirical investigation on organizational innovation and individual creativity" Information Systems and e-Business Management, 12, p.465 - 489

Petroulas, E., Brown, D., Sundin H., (2010) “Generational Characteristics and Their Impact on Preference for Management Control Systems", Australian Accounting Review, Issue 3, No. 54 Vol. 20, p221-240

Pieters, Rik; Wedel, Michel; Batra, Rajeev., (2010) "The Stopping Power of Advertising: Measures and Effects of Visual Complexity, Journal of Marketing. September, Vol. 74 Issue 5, p48-60. 
Pritchard, K., Whiting, R. (2014) "Baby boomers and the lost generation: on the discursive construction of generations at work", Organization Studies. November, Vol. 35 Issue 11, p 1605 - 1626

Reinartz, W.; Saffert, P. (2013) “Creativity in Advertising: When It Works and When It Doesn't". Harvard Business Review. June, Vol. 91 Issue 6, p106-112. 7p. 7

Reisenwitz, T. H., Iyer, R., (2009) “Differences in Generations X and Generation Y Implications fort he Organization and Marketers" Marketing Management Journal, Fall, p. 91-103

Roozen, I. (2013) "The impact of emotional appeal and the media context on the effectiveness of commercials for not-for-profit and for-profit brands" Journal of Marketing Communications, Vol. 19, No. 3, p.198-214

Santos, R., Gomes, S., Amorim, M. C. (2012) "Percepçâo Moral Entre Geraçöes Nas Organizaçöes Privadas: considerações sobre ensaios", Revista Pensamento \& Realidade, v. 29, n. 3 p.3 - 18

Schubert, K. (2012) "Analyzing Gender and Sexuality in Magazine Advertisements", American Journal of Sexuality Education, v7 n3 p212-218

Şimşek, Ö. F., Demir, M. (2014) “A Cross-Cultural Investigation into the Relationships Among Parental Support for Basic Psychological Needs, Sense of Uniqueness, and Happiness" The Journal of Psychology, 148(4), p.387-411

Tang, T.L., Cunningham P. H., Frauman E., Ivy M. I., Perry T. L., (2012) “Attitudes and Occupational Commitment among Public Personnel: Differences between Baby Boomers and Gen-Xers" Summer, Public Personneli Management Volume 41 No. 2, p.327-360

Tavener, M., Byles, J., (2014) “Expert perceptions of the popular baby boomer image”, Australasian Journal on Ageing, December, Vol 33 No 4, p.E31-E35

Torlak, N.. (2011) "Use/Abuse of Female Sexuality in Marketing" Megatrend Review., Vol. 8 Issue 2, p539-554. $16 \mathrm{p}$.

Trevor, T., (2007) "Brookings Study Profiles Boomer Population Growth", National Underwriter / Life \& Health Financial Services. Jul/16, Vol. 111 Issue 27, p34-40.

Valkeneers, G., Vanhoomissen, T. (2012) "Generations living their own life: The differences in lifestyle and consumer behaviour between busters and baby boomers".Journal of Customer Behaviour. Spring, Vol. 11 Issue 1 , p53-68

Walter, W., Hauck, J. R., Alland, O. (1977) "Wald's Test as Applied to Hypotheses in Logit Analysis" Journal of the American Statistical Association, Dec., Vol. 72, No 360, Theory and Methods Section, pp.851-853

West, D.; Caruana, A.; Leelapanyalert, K. (2013) "Judging Creativity in Advertising at Award Shows"., Journal of Advertising Research. Sep, Vol. 53 Issue 3, p324-338.

Yaşa, E., Mucan B., (2010) “Consumption and Elderly Consumers: A Literature Review”, Çağ University Journal of Social Sciences, 7(2), December, p.1-15

Yolbulan, O. E., Yalman, N., (2013) “Controversial Advertising in Turkey: A Cross-Generational Study”, Managerial and Economical Sciences Faculty Journal of Hacettepe University, 31(2) pp.135-152

Zwilling, M.; Fruchter, G. E. (2013) “Matching Product Attributes To Celebrities Who Reinforce the Brand: An Innovative Algorithmic Selection Model”, Journal of Advertising Research., December, Vol. 53 Issue 4, p391-410. 